Check for updates

Cite this: RSC Adv., 2017, 7, 51036

Received 18th September 2017 Accepted 29th October 2017

DOI: $10.1039 / c 7 r a 10340 a$

rsc.li/rsc-advances

\section{The characteristics of mineralogy, morphology and sintering during co-combustion of Zhundong coal and oil shale}

\author{
Yang Lu, Ying Wang, Yuqiong Zhao, Zheng Wei, Yuan Li, Wuxing Hao \\ and Yongfa Zhang (iD) *
}

The high-sodium coal from Zhundong region induces severe ash-related problems during combustion. Oil shale rich in silicon and aluminum has been adopted as an additive of Zhundong coal during cocombustion to investigate the characteristics of mineralogy, morphology and sintering at various temperatures and blending ratios in this study. The size distributions of the ash depositions have also been determined. The study results reveal that the fluxing minerals, such as sodium-based compounds, with sizes less than $10 \mu \mathrm{m}$ are dominant in Zhundong coal. These fine particles may present in a molten or sintering state at high temperature. Some refractory minerals with size exceeding $10 \mu \mathrm{m}$, such as nepheline or anorthite, form during co-combustion. These irregular particles retain their shapes during combustion resulting from their high melting temperatures. The blending of oil shale can change the migration path of the sodium during combustion, indicating that sodium gradually migrates from the water-soluble phase to the aluminosilicate phase. The amount of ash particles less than $10 \mu \mathrm{m}$ decreases from $84.31 \%$ to $40.29 \%$ with an increase in temperature. Furthermore, the refractory minerals with high melting point and high viscosity can result in high sintering temperature. The sintering temperature increases from $700{ }^{\circ} \mathrm{C}$ to $1055{ }^{\circ} \mathrm{C}$ when the blending ratio of oil shale reaches $20 \%$ and combustion temperature reaches $1050{ }^{\circ} \mathrm{C}$. In addition, 30-50\% sodium-based compounds volatilize to the gaseous phase during combustion of Zhundong coal. When the proportion of oil shale reaches $10 \%$, and combustion temperature is $850{ }^{\circ} \mathrm{C}$, sodium volatility will decrease to the lowest point of $14.49 \%$, which can suppress ash sintering to a large extent.

\section{Introduction}

The Zhundong region is situated in the east of the Junggar Basin, Xinjiang, China, where the coal resource is abundant, with prognostic reserves of 390 billion tons. This can meet the demand of China's coal consumption for 100 years based on the current annual average consumption., ${ }^{1,2}$ Zhundong coal ranges from lignite to sub-bituminous, which is obviously characterized by a low content of ash and sulfur, moderate calorific value and thus high quality..$^{3-6}$ It has been widely considered as one of the most important coal resources in China, which possesses a wide research and application potential. However, Zhundong coal applied as a fuel material has been characterized by a high AAEMs level which is attributed to the local alkaline geographical environment caused by a marine sedimentary coalfield. Especially, the content of sodium oxide exceeds $2 \%$ in the ash, the highest even exceeds $10 \%$, which is much higher than other steam coals. ${ }^{7}$ It is well known that the mineral constituents of coal exert a significant effect on thermal transformation efficiency of coal combustion

Key Laboratory of Coal Science and Technology, Ministry of Education and Shanxi Province, Taiyuan University of Technology, Taiyuan 030024, China. E-mail: yongfaz@tyut.edu.cn and safety of boilers operation. In some power plants, massive combustion of high sodium Zhundong coal has led to ash-related problems in the furnace wall and heat exchange surface of coalfired boilers, such as fouling, slagging and sintering, which influence safe operation and service life of boilers, even results in boiler collapse. ${ }^{8}$ The volatilization of sodium-based compounds in Zhundong coal could be one of the major factors during combustion. ${ }^{9}$ Therefore, it is of theoretical value and practical significance to study the slagging and sintering mechanism and control technology of sodium element by means of investigating the characteristics of mineralogy, morphology and sintering of the ash in order to have Zhundong coal been applied widely.

Yang et al. adopted improved sequential extraction method to study the content of sodium in different modes. The result indicated that the sodium in Zhundong coal was mainly dominated by water-soluble sodium, which approximately accounted for $50-85 \%$ of the total sodium. ${ }^{10}$ The volatility of water soluble sodium at high temperature was considered to be noxious during Zhundong coal combustion in boilers of power plants. Meanwhile, Zhou et al. evaluated the mineral phases of Zhundong coal ash under oxy-fuel combustion, and revealed that the main mineral phases are $\mathrm{NaCl}$, quartz, calcite, anhydrite, and andradite, which was consistent with the research 
result by Shen. ${ }^{\mathbf{1 1 , 1 2}}$ Among these minerals, $\mathrm{NaCl}$ was considered as water-solute sodium which played a dominated role in slagging and sintering performance. Xu et al. studied ash formation during combustion of Zhundong coal in a drop tube furnace and proposed that the ash of Zhundong coal had a large amount of particles with sizes less than $10 \mu \mathrm{m}$ which typically rich in $\mathrm{Ca}$, $\mathrm{Fe}$, and $\mathrm{Mg} .^{2} \mathrm{Li}$ et al. investigated the formation of fine particulates from Zhundong coal during combustion and revealed that fine particles $(<10 \mu \mathrm{m})$ rich in $\mathrm{Na}, \mathrm{S}$, and $\mathrm{Cl}$ had agglomerated and stuck to coarse ash particles $(>10 \mu \mathrm{m})$, indicating sintering had occurred. ${ }^{13}$ In addition, sintering temperature has been widely considered as a criterion for the evaluation of coal ash slagging tendency. ${ }^{6,14}$ Llorente concluded that kaolin, lime, calcined dolomite, and ophite could reduce the sintering behaviour, whereas silica did not efficiently reduce the sintering tendency of biomass ash. ${ }^{15}$

A few strategies to alleviate ash-related problem caused by sodium during Zhundong combustion have been proposed in the previous research, such as, pretreatment, ${ }^{16-18}$ addition of less-fouling coal, ${ }^{19-23}$ different additives blending ${ }^{24-26}$ as well as modifying boiler structure and optimizing operating conditions,${ }^{27}$ which have some limitations and shortcomings. Based on the current researches, co-combustion of silicon-aluminumrich additives could inhibit sodium volatility, which is one of the effective modes to solve the ash-related problems. ${ }^{28}$ When Zhundong coal was ashed with silicon-rich Heilongjiang coal, Wang et al. drew a conclusion that sodium volatility could be non-obvious if $\mathrm{SiO}_{2} / \mathrm{Na}_{2} \mathrm{O}$ or $\left(\mathrm{SiO}_{2}+\mathrm{Al}_{2} \mathrm{O}_{3}\right) / \mathrm{Na}_{2} \mathrm{O}$ in the blending coal sample were more than 20 or 25 , respectively. ${ }^{29}$ Wei et al. blended Zhundong coal with $\mathrm{SiO}_{2}$, kaolin and fly ash respectively, compared the effects of three additives on capturing sodium and it turned out that the effect of $\mathrm{SiO}_{2}$ was best at a most appropriate temperature of $1000{ }^{\circ} \mathrm{C} .{ }^{30} \mathrm{Xu}$ et al. investigated the efficiency of capturing sodium during co-combustion Zhundong coal with silicon-aluminum-rich kaolin, and the result showed that the more the kaolin content was, the better the capturing efficiency was, conversely, the higher the temperature was and the bigger the particle size was, then the lower the capturing efficiency is. Furthermore, $70 \%$ sodium could be captured with kaolin content ratio of $6 \%$, particle size of $11 \mu \mathrm{m}$ and combustion temperature of $1200{ }^{\circ} \mathrm{C} .^{31}$

The oil shale, a new type fuel with rich reserve in Xinjiang Provence, has been adopted as an additive of Zhundong coal during co-combustion, which is flammable sedimentary rock rich in silicon and aluminum elements. ${ }^{32}$ Those two elements are beneficial components for coal ash, which have an inhibitory effect on sodium volatility of Zhundong coal and change the path of sodium transformation during co-combustion, furthermore can enhance the sintering temperature. To date, the co-combustion of Zhundong coal and oil shale is rarely reported, some relevant mechanisms should be investigated for deeper. Thus, in this paper, the mineralogy and morphology of the blended fuel during co-combustion were studied through XRD and SEM-EDS. In addition, the variation of particle size and sintering temperature of the blended fuel would also be investigated. These above could provide valuable reference for clean and efficient utilization of Zhundong coal.

\section{Materials and methods}

\subsection{Coal and additive samples}

A "run of mine" Zhundong coal (ZD) and Changji oil shale (CJ) were used in this current study, which were crushed, ground and screened to $75-100 \mu \mathrm{m}$. The proximate analysis, ultimate analysis and ash component analysis of Zhundong coal and oil shale were performed in Table 1 . It could be obviously seen that Zhundong coal has higher moisture and lower ash content than oil shale. In addition, it has been widely considered that the base to acid ratio, denoted as $\mathrm{B} / \mathrm{A}, \mathrm{B} / \mathrm{A}=\left(\mathrm{Na}_{2} \mathrm{O}+\mathrm{MgO}+\mathrm{CaO}+\right.$ $\left.\mathrm{K}_{2} \mathrm{O}+\mathrm{Fe}_{2} \mathrm{O}_{3}\right) /\left(\mathrm{SiO}_{2}+\mathrm{Al}_{2} \mathrm{O}_{3}+\mathrm{TiO}_{2}\right)$, is also an important index in slagging and sintering propensities according to previous researches. At the same time, Zhundong coal has a higher content of alkali metal and alkali earth metals (AAEMs), and lower content of $\mathrm{SiO}_{2}$ and $\mathrm{Al}_{2} \mathrm{O}_{3}$ than oil shale, which results in higher $\mathrm{B} / \mathrm{A}$ and slagging tendency. In contrast, oil shale has a higher content of $\mathrm{SiO}_{2}$ and $\mathrm{Al}_{2} \mathrm{O}_{3}$, and lower content of AAEMs, which leads to lower $\mathrm{B} / \mathrm{A}$ and slagging propensity.

In addition, coal blends were prepared by physically mixing ZD and CJ samples with five blending ratios in the weight percentage: $100: 0,95: 5,90: 10,85: 15,80: 20$, which were termed as ZD, MF1, MF2, MF3, and MF4 for convenience. These samples were dries in an air blowing thermostatic drying oven at $105{ }^{\circ} \mathrm{C}$ for $24 \mathrm{~h}$ and stored in sealed bags for latter use.

\subsection{Coal ashing}

A programmable high-temperature tube furnace SRJK-2.5-13 was applied in the ashing experiment, with maximum temperature of $1350{ }^{\circ} \mathrm{C}$, furnace pot size of $2-\phi 22 \times 180 \mathrm{~mm}$, voltage of

Table 1 Properties of the Zhundong coal and Changji oil shale

\begin{tabular}{lcr}
\hline & $\mathrm{ZD}$ & $\mathrm{CJ}$ \\
\hline Proximate analysis (wt\% as air dried base) & \\
$\mathrm{M}$ & 12.93 & 2.92 \\
$\mathrm{~A}$ & 5.48 & 78.72 \\
$\mathrm{~V}$ & 25.27 & 13.18 \\
$\mathrm{FC}$ & 56.32 & 5.18 \\
& & \\
Ultimate analysis (wt\% as air dried base) & \\
$\mathrm{C}$ & 65.29 & 9.06 \\
$\mathrm{H}$ & 2.96 & 1.84 \\
$\mathrm{O}$ & 15.10 & 6.73 \\
$\mathrm{~N}$ & 0.54 & 0.48 \\
$\mathrm{~S}$ & 0.16 & 0.25 \\
& & \\
$\mathrm{Ash}$ composition (wt\%) & & 63.50 \\
$\mathrm{SiO}_{2}$ & 18.26 & 22.24 \\
$\mathrm{Al}_{2} \mathrm{O}_{3}$ & 8.98 & 0.58 \\
$\mathrm{CaO}$ & 27.30 & 5.24 \\
$\mathrm{Fe}_{2} \mathrm{O}_{3}$ & 7.28 & 2.56 \\
$\mathrm{~K}_{2} \mathrm{O}$ & 0.52 & 1.70 \\
$\mathrm{MgO}$ & 0.88 \\
$\mathrm{Na}_{2} \mathrm{O}$ & 4.58 & 0.08 \\
$\mathrm{SO}_{3}$ & 20.34 & 0.09 \\
$\mathrm{P}_{2} \mathrm{O}_{5}$ & 0.38 & 0.78 \\
$\mathrm{TiO}_{2}$ & 0.34 & 0.12 \\
$\mathrm{~B} / \mathrm{A} \mathrm{ratio}$ &
\end{tabular}


0-220 V, power of $2.5 \mathrm{~kW}$. In the experiment, ZD and CJ were put into the tube furnace for ashing, final combustion temperature was set to $550{ }^{\circ} \mathrm{C}$ for low temperature ashing. Because some minerals such as AAEMs would escape to gaseous phase at high temperature during coal combustion, which could cause relatively large errors in the analysis of mineral composition. At the same time, MF1, MF2, MF3, MF4 were conducted separately with final temperature of $850{ }^{\circ} \mathrm{C}, 950{ }^{\circ} \mathrm{C}, 1050{ }^{\circ} \mathrm{C}$, respectively. All ash samples were heated in air atmosphere with the flow rate of $0.4 \mathrm{~L} \mathrm{~min} \mathrm{~min}^{-1}$ and remained constant for 2 hours under final temperature to make sure the mixed fuel sample were ashed completely. Furthermore, the heating rate was controlled to $10{ }^{\circ} \mathrm{C} \min ^{-1}$ below $600{ }^{\circ} \mathrm{C}$, and $5{ }^{\circ} \mathrm{C} \min ^{-1}$ above $600{ }^{\circ} \mathrm{C}$.

\subsection{Chilling and drying}

The ash samples obtained from co-combustion were rapidly immersed in liquid nitrogen for chilling which can be cooled down to less than $300{ }^{\circ} \mathrm{C}$ within $2 \mathrm{~s}$ in order to prevent a crystal phase change during the temperature drop. After these samples were cooled down to room temperature, they were dried in a thermostatic drying oven at $105{ }^{\circ} \mathrm{C}$ for $2 \mathrm{~h}$. The ash samples after chilling and drying were subjected to subsequent determination and characterization.

\subsection{XRD, SEM-EDS and particle size analysis}

The Rigaku MiniFlex600 X-ray diffractometer (XRD) would be adopted to identify the mineral phase in the ash samples, with radiation source of $\mathrm{Cu} \mathrm{K} \alpha$, tube voltage of $40 \mathrm{kV}$, tube current of $15 \mathrm{~mA}$, scanning rate of $8^{\circ} \mathrm{min}^{-1}$, scanning range of $20-60^{\circ}$, and also software jade 6.5 could be applied for comparison of absorption peak and ICDD Power Diffraction File (PDF) database to confirm the mineral composition of ash samples with different target temperature and blending ratio. In addition, different characteristic absorption peaks represent different mineral compositions of coal ashing, and the strength of characteristic absorption peak also represents the content of mineral composition. ${ }^{33}$

The texture, morphological characteristic and spot elemental composition of the ashes particles in the deposit were observed using a Tescan Vaga 3 scanning electron microscopy (SEM) coupled with an Oxford X-ray energy dispersive spectroscopy (EDS). Each sample was scattered on a carbon tape carefully so that the particles could be observed individually.

The particle size distribution of each ash sample was also determined using a CILAS-1190 laser particle size analyzer in wet mode with a measurement range of $0.04-2500 \mu \mathrm{m}$. Each measurement was repeated three times to ensure good repeatability of the results.

\subsection{Sintering temperature determination}

A designed pressure-drop device, as introduced elsewhere, ${ }^{\mathbf{1 4}}$ was used to determine the sintering temperature of the ash samples prepared in the preceding section. Briefly, 0.4-0.8 $\mathrm{g}$ of ash was compacted into a pellet under a pressure of $0.8 \mathrm{MPa}$ which was then heated in a tube furnace at a heating rate of $6.7^{\circ} \mathrm{C} \mathrm{min}^{-1}$ in inert atmosphere $\left(\mathrm{N}_{2}\right)$ at a flow rate of $10 \mathrm{~mL} \mathrm{~min}^{-1}$. The gauge pressure prior to the pellet and the temperature of the pellet were continuously recorded. The sintering temperature of the ash samples was measured based on the first-order and secondorder derivatives of the pressure-drop curves as a function of temperature in accordance with the research paper, which was an improved and accurate method compared to other sintering temperature measurement.

\subsection{Sodium content determination}

The sodium content of the ash sample was determined using the ICAP 6000 Series inductively coupled plasma-optical emission spectrometer (ICP-OES) produced by Thermo Fisher Scientific. Each ash sample would be digested with a hydrofluoric acid-perchloric acid mixture to obtain the sample solution before the determination of the absorbency by ICP-OES, at a radio frequency power of $1.15 \mathrm{~kW}$, plasma gas flow rate of 10.0 $\mathrm{L} \mathrm{min}{ }^{-1}$, auxiliary gas flow rate of $0.75 \mathrm{~L} \mathrm{~min}^{-1}$, atomization gas flow rate of $0.50 \mathrm{~L} \mathrm{~min}{ }^{-1}$, peristaltic pump flow rate of 1.5 $\mathrm{mL} \min ^{-1}$, and integration time of $5 \mathrm{~s}$ (average of three tests), with an axial torch and a radial viewing mode.

\subsection{Volatilization proportion of sodium}

To better present the volatilization characteristic of sodium in the ash sample after co-combustion, the following parameters were introduced for calculation.

Sodium content, $m_{1}\left(\mathrm{mg} \mathrm{g}^{-1}\right)$, of mixed fuel after ashing (coal-based)

$$
m_{1}=m_{1}^{\prime} \times A
$$

where $m^{\prime}{ }_{1}=$ sodium content of mixed fuel ash after ashing (ashbased), $\mathrm{mg} \mathrm{g}^{-1}$, and $A=$ yield of ash produced from mixed fuel ashing.

Percentage of sodium residue in mixed fuel ash, $\alpha(\%)$

$$
\alpha=\frac{m_{1}}{m_{0}} \times 100 \%=\frac{m_{1}^{\prime} \times A}{m_{0}} \times 100 \%
$$

where $m_{0}=$ sodium content of mixed fuel before ashing (coalbased), $\mathrm{mg} \mathrm{g}^{-1}$.

Volatilization proportion of sodium, $\beta$ (\%), at combustion temperature $T$, which was calculated as follows:

$$
\beta=1-\alpha=1-\frac{m_{\mathrm{Na}, \mathrm{MF}}(\omega, T)}{m_{\mathrm{Na}, \mathrm{ZD}}+m_{\mathrm{Na}, \mathrm{CJ}}} \times 100 \%
$$

where $m_{\mathrm{Na}, \mathrm{MF}}(\omega, T)=$ content of sodium in the ash of mixed fuel with an oil shale blending ratio of $\omega$ and final combustion temperature of $T ; m_{\mathrm{Na}, \mathrm{ZD}}=$ content of sodium in Zhundong coal; and $m_{\mathrm{Na}, \mathrm{CJ}}=$ content of sodium in Changji region oil shale.

\section{Results and discussion}

\subsection{Ash mineralogy}

Fig. 1 shows the XRD pattern of the ash samples of ZD, CJ and mixed fuel heated at different temperatures and blending ratios in air atmosphere. In Fig. 1(b)-(d), only the $20-60^{\circ}$ XRD patterns 
are shown here, because the ash samples of mixed fuel had weak absorption peaks at $10-20^{\circ}$ and $60-90^{\circ}$. It can be evidently observed that the combustion temperature plays a significant role in the ash mineralogy transformation process, by contrast, the oil shale ratio has little influence.

Fig. 1(a) shows that the primary mineral phases in the $\mathrm{ZD}$ ash deposit at combustion temperature of $550{ }^{\circ} \mathrm{C}$ are mainly identified as anhydrite $\left(\mathrm{CaSO}_{4}\right)$, quartz $\left(\mathrm{SiO}_{2}\right)$, thenardite $\left(\mathrm{Na}_{2} \mathrm{SO}_{4}\right)$, halite $(\mathrm{NaCl})$. This coal also contains calcite $\left(\mathrm{CaCO}_{3}\right)$, larnite $\left(\mathrm{Ca}_{2} \mathrm{SiO}_{4}\right)$, and periclase $(\mathrm{MgO})$ in minor quantities. Among these minerals, the fluxing minerals including calcite, anhydrite, thenardite and halite with high viscosity and low melting point are dominant while the refractory minerals such as quartz, larnite and periclase are deficient, indicating severe sintering tendency and high deposition propensity. ${ }^{34,35}$ At the same time, the primary minerals in $\mathrm{CJ}$ ash deposit are identified as $\mathrm{SiO}_{2}$ and $\mathrm{Al}_{2} \mathrm{O}_{3}$ in major quantities, which are consistent with the ash composition analysis results in Table 1 . These minerals are refractory phases which suggest high melting point and low deposition propensity.

Fig. 1(b) shows that the mineral compositions in the ash deposition of mixed fuels with different blending ratio of oil shale at combustion temperature of $850{ }^{\circ} \mathrm{C}$, are mainly quartz $\left(\mathrm{SiO}_{2}\right)$, anhydrite $\left(\mathrm{CaSO}_{4}\right)$, albite $\left(\mathrm{NaAlSi}_{3} \mathrm{O}_{8}\right)$, anorthite
$\left(\mathrm{CaAl}_{2} \mathrm{Si}_{2} \mathrm{O}_{8}\right)$ and kyanite $\left(\mathrm{Al}_{2} \mathrm{O}_{3} \cdot \mathrm{SiO}_{2}\right)$. It can be seen that all the absorption peaks of halite, thenardite, larnite and calcite disappears which will result from a series of physical and chemical changes. The entire amount of the halite and thenardite in ZD volatilizes into the gas phase which will adhere to the heat exchange surface and boiler wall. Meanwhile, the calcite disappears which suggests that it decomposes into $\mathrm{CaO}$ and $\mathrm{CO}_{2}$. Furthermore, larnite decomposes into $\mathrm{CaO}$ and $\mathrm{SiO}_{2}$. The generated $\mathrm{CaO}$ reacts with $\mathrm{SiO}_{2}$ and $\mathrm{Al}_{2} \mathrm{O}_{3}$ in oil shale to form anorthite with a melting point of $1553^{\circ} \mathrm{C}$. Also, $\mathrm{NaCl}$ in ZD reacts with $\mathrm{SiO}_{2}$ and $\mathrm{Al}_{2} \mathrm{O}_{3}$ in oil shale to form albite with a melting point of $1180^{\circ} \mathrm{C}$. Albite readily reacts with $\mathrm{Fe}_{2} \mathrm{O}_{3}, \mathrm{CaO}$ and some aluminosilicates to form a eutectic with a low ash fusion point of the mixed fuel. In addition, $\mathrm{SiO}_{2}$ and $\mathrm{Al}_{2} \mathrm{O}_{3}$ in the mixed fuel react to form kyanite which will easily transform into mullite at high temperatures.

Fig. 1(c) shows that the mineral compositions in the ash deposition of mixed fuels with different blending ratio of oil shale at combustion temperature of $950{ }^{\circ} \mathrm{C}$, are mainly quartz, anhydrite, anorthite, kyanite, gehlenite $\left(\mathrm{Ca}_{2} \mathrm{Al}_{2} \mathrm{SiO}_{7}\right)$ and akermanite $\left(\mathrm{Ca}_{2} \mathrm{MgSi}_{2} \mathrm{O}_{7}\right)$. It can be seen that the kyanite in the ash of the mixed fuel at the temperature of $950^{\circ} \mathrm{C}$ is more than that at $850^{\circ} \mathrm{C}$, indicating that more kyanite is further generated with the increase in combustion temperature. Meanwhile, the
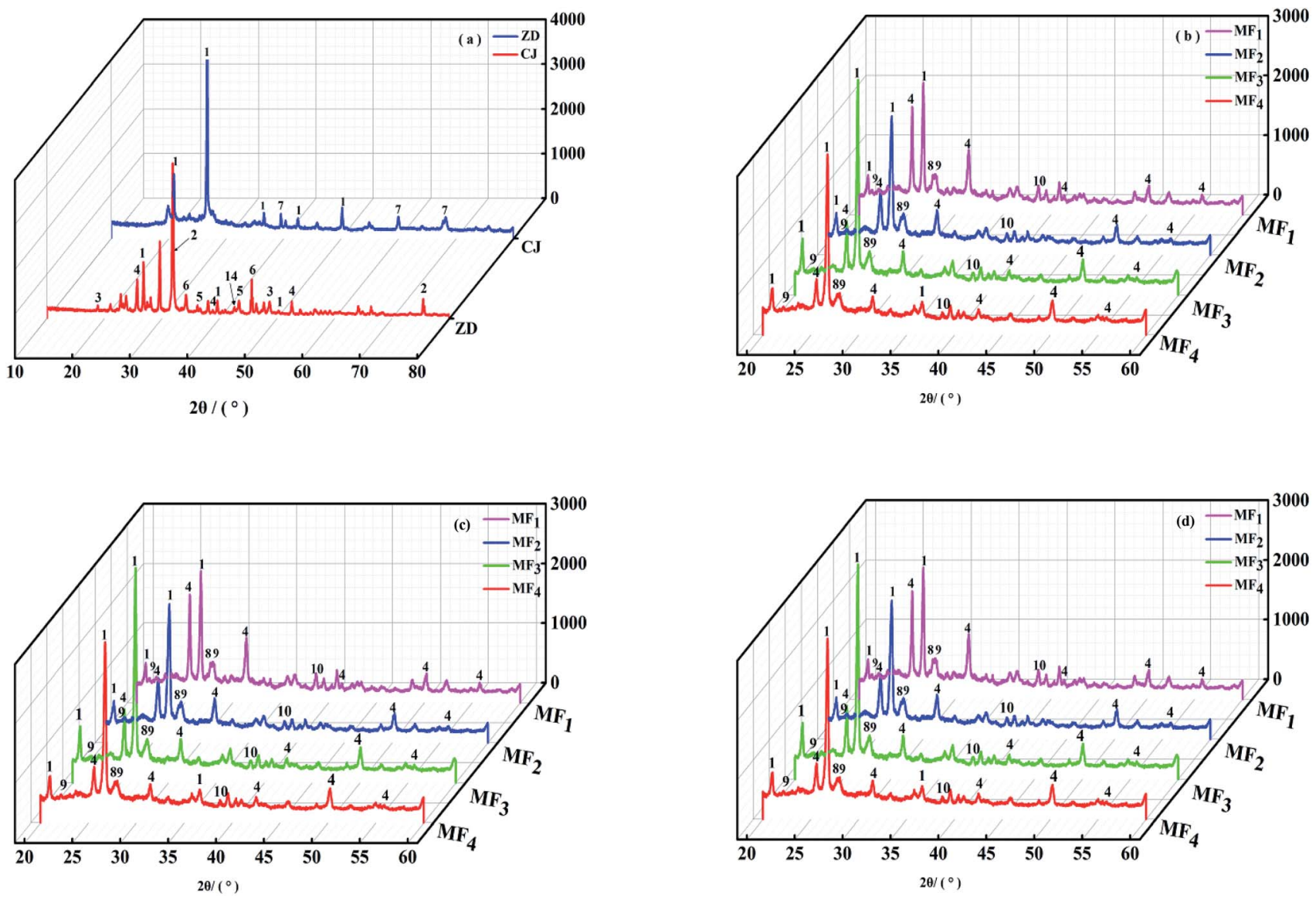

Fig. 1 The XRD pattern of ash samples of ZD, CJ and mixed fuel obtained at different blending ratios and temperatures. 1 . Quartz; 2 . halite; 3. thenardite; 4. anhydrite; 5 . calcite; 6 . larnite; 7. $\mathrm{Al}_{2} \mathrm{O}_{3}$; 8. anorthite; 9. albite; 10. kyanite; 11. anorthite; 12 . nepheline; 13 . mullite; 14 . periclase; 15. gehlenite; 16. akermanite; 17. diopside. 
anorthite in the ash of the mixed fuel at temperature of $950{ }^{\circ} \mathrm{C}$ is less than that at $850{ }^{\circ} \mathrm{C}$, resulting from that the anorthite reacts with $\mathrm{CaO}$ to form gehlenite with a melting point of $1593{ }^{\circ} \mathrm{C}$. In addition, the $\mathrm{CaO}$ generated from former reaction reacts with periclase in $\mathrm{ZD}$ coal and quartz in oil shale to form akermanite with a melting point of $1450{ }^{\circ} \mathrm{C}$.

Fig. 1(d) shows that the mineral compositions in the ash deposition of mixed fuels with different blending ratio of oil shale at combustion temperature of $1050{ }^{\circ} \mathrm{C}$, are mainly quartz, gehlenite, anhydrite, akermanite, mullite $\left(3 \mathrm{Al}_{2} \mathrm{O}_{3} \cdot 2 \mathrm{SiO}_{2}\right)$, nepheline $\left(\mathrm{NaAlSiO}_{4}\right)$ and diopside $\left(\mathrm{CaMg}\left(\mathrm{SiO}_{3}\right)_{2}\right)$. It can be seen that all the absorption peaks of the anorthite in the ash of the mixed fuel disappears, owing to that all of the anorthite transforms into gehlenite with the temperature increase. Also, the kyanite transforms into mullite with a melting point of $1850{ }^{\circ} \mathrm{C}$, which is consistent with previous research results. ${ }^{36}$ In addition, albite disappears and decomposes into nepheline with a melting point of $1550{ }^{\circ} \mathrm{C}$ and quartz. Nepheline can also be produced by the reaction of sodium-containing compounds in $\mathrm{ZD}$ coal with $\mathrm{SiO}_{2}$ and $\mathrm{Al}_{2} \mathrm{O}_{3}$ in oil shale directly at this temperature. Akermanite decomposes into diopside with a melting point of $1391{ }^{\circ} \mathrm{C}$ and $\mathrm{CaO}$. And diopside can also generated by the reaction of $\mathrm{CaO}, \mathrm{MgO}$, and $\mathrm{SiO}_{2}$ in the ash of the mixed fuel directly at this temperature.

These reactions above are given as follows:

$$
\begin{aligned}
& \mathrm{CaCO}_{3} \rightarrow \mathrm{CaO}+\mathrm{CO}_{2} \\
& \mathrm{Ca}_{2} \mathrm{SiO}_{4} \rightarrow 2 \mathrm{CaO}+\mathrm{SiO}_{2} \\
& 2 \mathrm{NaCl}+6 \mathrm{SiO}_{2}+\mathrm{Al}_{2} \mathrm{O}_{3}+\mathrm{H}_{2} \mathrm{O} \rightarrow 2 \mathrm{NaAlSi}_{3} \mathrm{O}_{8}+2 \mathrm{HCl} \\
& \mathrm{CaO}+2 \mathrm{Al}_{2} \mathrm{O}_{3}+\mathrm{SiO}_{2} \rightarrow \mathrm{CaAl}_{2} \mathrm{Si}_{2} \mathrm{O}_{8} \\
& \mathrm{Al}_{2} \mathrm{O}_{3}+\mathrm{SiO}_{2} \rightarrow \mathrm{Al}_{2} \mathrm{O}_{3} \cdot \mathrm{SiO}_{2} \\
& \mathrm{CaAl}_{2} \mathrm{Si}_{2} \mathrm{O}_{8}+\mathrm{CaO} \rightarrow \mathrm{Ca}_{2} \mathrm{Al}_{2} \mathrm{SiO}_{7} \text { (anorthite } \rightarrow \text { gehlenite) } \\
& 2 \mathrm{CaO}+\mathrm{MgO}+2 \mathrm{SiO}_{2} \rightarrow \mathrm{Ca}_{2} \mathrm{MgSi}_{2} \mathrm{O}_{7} \\
& \mathrm{NaAlSi}_{3} \mathrm{O}_{8} \rightarrow \mathrm{NaAlSiO}_{4}+2 \mathrm{SiO}_{2} \text { (albite } \rightarrow \text { nepheline) } \\
& 3 \mathrm{Al}_{2} \mathrm{O}_{3} \cdot \mathrm{SiO}_{2} \rightarrow 3 \mathrm{Al}_{2} \mathrm{O}_{3} \cdot 2 \mathrm{SiO}_{2}+\mathrm{SiO}_{2} \text { (kyanite } \rightarrow \text { mullite) } \\
& 2 \mathrm{NaCl}+2 \mathrm{SiO}_{2}+\mathrm{Al}_{2} \mathrm{O}_{3}+\mathrm{H}_{2} \mathrm{O} \rightarrow 2 \mathrm{NaAlSiO}_{4}+2 \mathrm{HCl} \\
& \mathrm{Ca}_{2} \mathrm{MgSi}_{2} \mathrm{O}_{7} \rightarrow \mathrm{CaMg}\left(\mathrm{SiO}_{3}\right)_{2}+\mathrm{CaO} \\
& \text { (akermanite } \rightarrow \text { diopside) } \\
& \mathrm{CaO}+\mathrm{MgO}+2 \mathrm{SiO}_{2} \rightarrow \mathrm{CaMg}\left(\mathrm{SiO}_{3}\right)_{2}
\end{aligned}
$$

It can be distinctly known that all the ash deposition of mixed fuel heated at various temperatures with various blending ratios of oil shale contain a certain amount of quartz and anhydrite. This is because oil shale contains a large amount of $\mathrm{SiO}_{2}$ and the following reactions also produce it. Meanwhile, anhydrite is hard to volatilize which will decompose above $1700{ }^{\circ} \mathrm{C}$ in an oxidizing atmosphere. After blending oil shale in Zhundong coal, a series of physical and chemical changes have occurred in the ash of the mixed fuel during co-combustion, which can change the migration path of the sodium. The XRD patterns show that sodium gradually migrated from the watersoluble phase to the aluminosilicate phase, which has been deposited in the ash and inhabited to volatilize by the Si and $\mathrm{Al}$ in oil shale.

\subsection{Ash morphology and chemistry}

Fig. 2 presents typical ash depositions SEM images of ZD coal heated at $550{ }^{\circ} \mathrm{C}$ and mixed fuel containing $90 \% \mathrm{ZD}$ coal and $10 \%$ oil shale heated at $850{ }^{\circ} \mathrm{C}, 950{ }^{\circ} \mathrm{C}, 1050{ }^{\circ} \mathrm{C}$ and EDS results at selected spots of interest in order to investigate the morphology and chemistry. In addition, the particle size distributions of ash depositions are shown in Fig. 3.

As shown in Fig. 2(a), at combustion temperature of $550{ }^{\circ} \mathrm{C}$, it is evidently observed that an irregular ash particle in area 1 mostly consist of $\mathrm{Si}$ and $\mathrm{O}$, indicating the presence of quartz. Meanwhile, the spherical ash particle in area 2 has experienced fully molten at high temperature whose elemental compositions are mainly $\mathrm{Na}, \mathrm{S}$ and $\mathrm{O}$, suggesting that sodium sulfate exists. It is because of the low melting temperature of sodium sulfate that the spherical ash particle in area 2 is in the fusional state. In addition, the bonding ash particles aggregate in area 3 which is mainly composed of $\mathrm{Na}$ and $\mathrm{Cl}$, showing the present of halite. These fine particles have stuck with each other, and the particle sintering occur which is observed in the SEM image resulting from the low sintering temperature of halite. An irregular ash particle has been found in area 4 rich in $\mathrm{Ca}, \mathrm{S}$ and $\mathrm{O}$, which shows that calcium sulfate exits in ZD coal indubitably. In the ash deposition of ZD coal, discrete fine particles with sizes less than $10 \mu \mathrm{m}$ play a dominate role which account for $84.31 \%$ of total ash particles according to the ash particle size distribution of $\mathrm{ZD}$ coal as shown in Fig. 3. This is in agreement with the literature research studied by $\mathrm{Li}$. The fine particles rich in AAEMs (especially $\mathrm{Na}$ and $\mathrm{Ca}$ ) are fluxing minerals with size less than $10 \mu \mathrm{m}$, which have low sintering temperature and high viscosity. This can easily stimulate slagging tendency and enhance sintering propensity.

As shown in Fig. 2(b), at combustion temperature of $850{ }^{\circ} \mathrm{C}$, an oblate spherical ash particle in area 1 is observed whose elemental compositions are mainly $\mathrm{Si}$ and $\mathrm{O}$, suggesting the presence of quartz. Meanwhile, the coarse irregular ash particle exists in area 2 which is mainly composed of $\mathrm{Na}, \mathrm{Si}$ and $\mathrm{Al}$ according to the EDS result, indicating the presence of sodium aluminosilicate which is identified as albite further referring to the weight fraction of elements and result of XRD above. Some discrete fine particles less than $10 \mu \mathrm{m}$ aggregate on its surface so that particles sintering occur under this circumstance. In addition, the elemental compositions of the irregular ash particle mainly consist of $\mathrm{Ca}, \mathrm{S}$ and $\mathrm{O}$ (area 3 ) and $\mathrm{Ca}, \mathrm{Si}, \mathrm{Al}$ and $\mathrm{O}$ (area 4), indicating the existence of calcium sulfate and aluminosilicate. These irregular ash particles retain their shapes during combustion which resulted from their high melting temperatures.

As shown in Fig. 2(c), at combustion temperature of $950{ }^{\circ} \mathrm{C}$, it is evidently observed that the ash deposition consists of both 

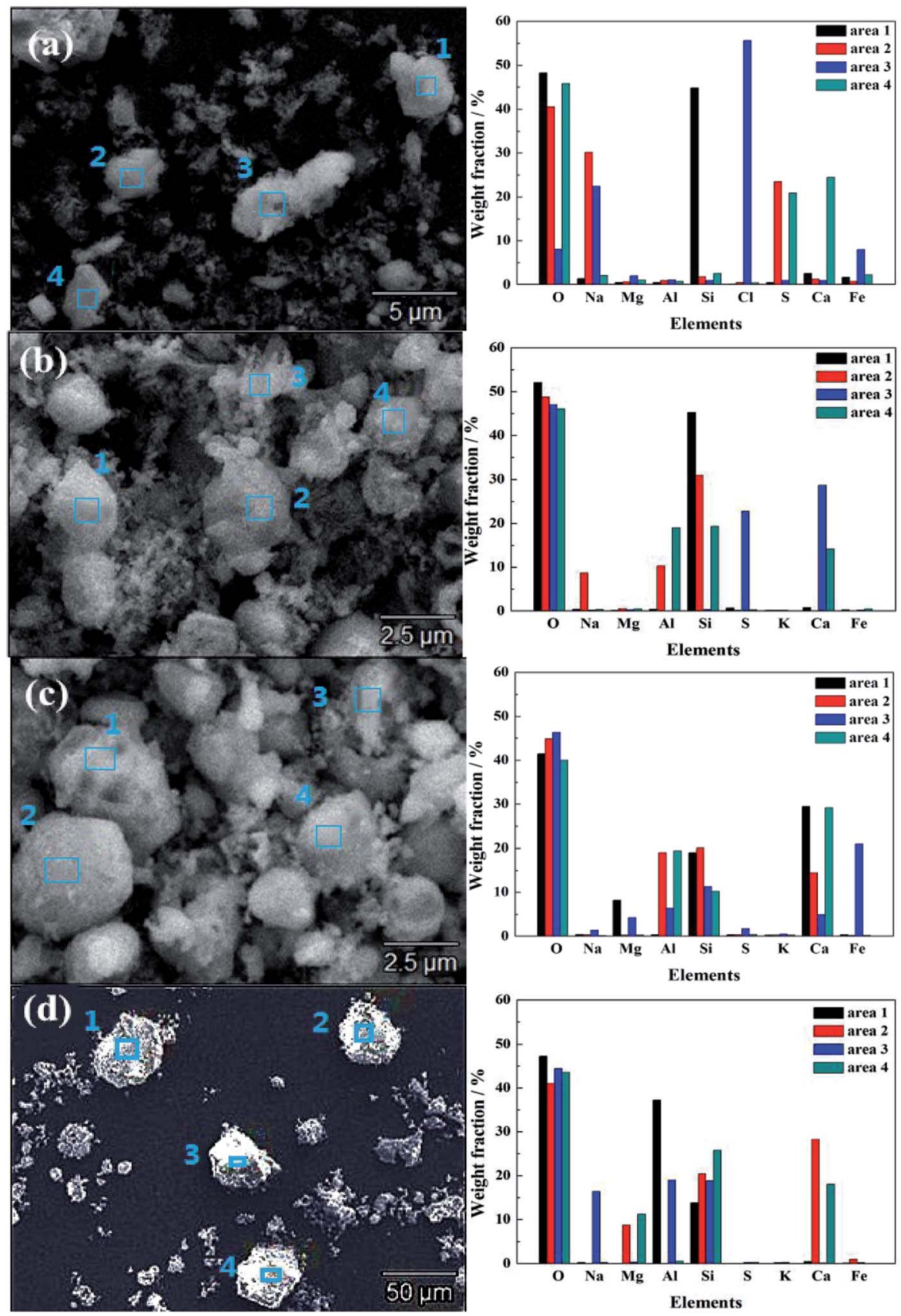

Fig. 2 Typical ash SEM images of ZD coal at temperature of (a) $550{ }^{\circ} \mathrm{C}$ and mixed fuel at temperatures of (b) $850{ }^{\circ} \mathrm{C}$, (c) $950{ }^{\circ} \mathrm{C}$, (d) $1050{ }^{\circ} \mathrm{C}$, and EDS results of elemental analysis at selected spots.

fine ash particles and large coarse ash particles. Large irregular particles rich in silicate or aluminosilicate with high melting point are dominated in the ash deposition. The large irregular ash particle in area 1 whose elemental compositions mainly consist of $\mathrm{Ca}, \mathrm{Mg}, \mathrm{Si}$ and $\mathrm{O}$, confirming the present of akermanite with size more than $10 \mu \mathrm{m}$. Meanwhile, the larger irregular spherical ash particle in area 2 is observed which is mostly composed of $\mathrm{Ca}, \mathrm{Si}, \mathrm{Al}$ and $\mathrm{O}$, indicating the of calcium aluminosilicate which is identified as anorthite further referring to the weight fraction of elements and result of XRD above. In addition, a molten agglomeration form in area 3 , which contains majority of $\mathrm{Fe}, \mathrm{Ca}, \mathrm{Mg}, \mathrm{Si}$ and $\mathrm{O}$, resulting from that the oxides of iron, calcium, magnesium and silicate lead to form a low-temperature eutectic. The irregular spherical ash particle in area 4 , is identical in the elemental composition with that in area 2, but different in weight fraction of each element, which is determined as gehlenite further according to the weight fraction of elements and result of XRD above. Furthermore, some discrete fine particles have adhered to gehlenite, resulting in a decrease in the amount of discrete fine ash particles, as shown in Fig. 3. 


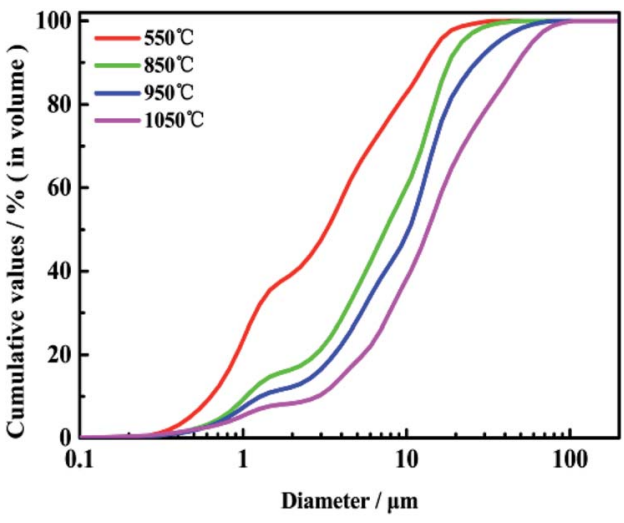

Fig. 3 Size distributions of ZD coal at temperature of $550{ }^{\circ} \mathrm{C}$ and mixed fuel at temperatures of $850^{\circ} \mathrm{C}, 950{ }^{\circ} \mathrm{C}, 1050^{\circ} \mathrm{C}$.

As shown in Fig. 2(d), at combustion temperature of $1050{ }^{\circ} \mathrm{C}$, it has obviously been found that an irregular coarse ash particle in area 1 whose elemental compositions are mainly $\mathrm{Si}, \mathrm{Al}$ and $\mathrm{O}$, which is probably large-size mullite with some fine ash particle stuck on it. Meanwhile, an oblate spherical ash particle mainly consisted of $\mathrm{Ca}, \mathrm{Si}, \mathrm{Al}$ and $\mathrm{O}$ has been observed in area 2, which is considered as calcium aluminosilicate with large size and high melting point. The large angular ash particle in area 3 is mostly composed of $\mathrm{Na}, \mathrm{Si}, \mathrm{Al}$ and $\mathrm{O}$ which is identified as sodium aluminosilicate, confirming the formation of nepheline according to the result of XRD above. Furthermore, another large angular ash particle has been found in area 4, with large amount of $\mathrm{Mg}, \mathrm{Ca}, \mathrm{Si}$ and $\mathrm{O}$, which is further considered as diopside. In addition, it has been shown that the dispersion of ash particle considerably increases and the amount of large ash particle with size more than $10 \mu \mathrm{m}$ also increase, which accounts for $60 \%$ approximately, resulting in the mitigation of sintering.

It has been firmly considered that the combustion temperature has a significant influence on the morphology and size distribution of ash deposition, resulting from the action of combustion on the mineral reaction. With an increase in combustion temperature, the amount of fine ash particle decreases and large ash particle increases. The amount of ash particle less than $10 \mu \mathrm{m}$ decreases from $84.31 \%$ at temperature of $550{ }^{\circ} \mathrm{C}$ to $40.29 \%$ at temperature of $1050{ }^{\circ} \mathrm{C}$ according to the curve of ash particle size distribution, as shown in Fig. 3. Some large ash particles have been found in SEM image resulting from the formation of some minerals rich in silicate and aluminum, such as nepheline, anorthite, mullite, akermanite etc., which are refractory minerals with low viscosity and high melting point, leading to mitigate slagging tendency and suppress sintering propensity.

\subsection{Sintering temperature of the ash}

The sintering of coal ash refers to the welding and bonding of adjacent powder particles under the effect of excessive surface free energy, which is one of the most important factors of bed material agglomeration, pipe fouling, heat-exchange surface slagging. ${ }^{37-39}$ Therefore, the sintering temperatures of ZD coal and mixed fuel ash are measured by a designed pressure-drop device to evaluate the effect of combustion temperature and oil shale blending. It has been firmly convinced that the higher sintering temperature, the lower sintering propensity and slagging tendency.

Fig. 4 shows that the sintering temperature of the ash samples of the mixed fuel heated at various temperatures. It can be clearly known that the sintering temperature increases first slightly and then decreases rapidly in general with an increase in the blending ratio of oil shale, regardless of any combustion temperatures. The sintering temperature of coal ash is related to mineral components in the ash, the reactions among them and the formation of a low-temperature eutectic. ${ }^{40}$ The more content of basic oxides such as $\mathrm{Na}_{2} \mathrm{O}, \mathrm{CaO}, \mathrm{MgO}$ indicates low sintering temperature and high slagging tendency in combustion condition. On the contrary, the more content of acidic oxides such as $\mathrm{SiO}_{2}$ and $\mathrm{Al}_{2} \mathrm{O}_{3}$ indicates high sintering temperature and low slagging tendency in combustion condition. ${ }^{41,42}$

The Zhundong coal ash with low sintering temperature of $700-730{ }^{\circ} \mathrm{C}$ which is due to the high alkali and alkaline earth metals content which are fluxing minerals according to the results of ash component analysis and XRD. The acidic cations with high ionic potential $\left(\mathrm{Na}^{+}, \mathrm{Ca}^{2+}, \mathrm{Mg}^{2+}, \mathrm{Fe}^{3+}\right)$ are easily combined with oxygen to form complex ions or polymers, while the alkaline cations $\left(\mathrm{Si}^{4+}, \mathrm{Al}^{3+}\right)$ are oxygen donors, which can terminate the agglomeration of the polymers and reduce their viscosity, showing the fluxing effect. In addition, these crystalline fluxing minerals will act as the amorphous minerals under the action of the surface tension showing the flowing state and stimulating ash sintering. When the oil shale blending ratio is in the range of $0-5 \%$, the sintering temperature decreases gradually. It is for the reason that the proportion of mineral component in the ash deposition is in the low-temperature eutectic region of the ternary phase diagram which is consistent with the research results of $\mathrm{Li}^{.13,43}$ When the oil shale blending ratio increases further, the sintering temperature increases rapidly, which is because the ash depositions of the mixed fuel contain higher contents of refractory minerals but lower contents of fluxing minerals.

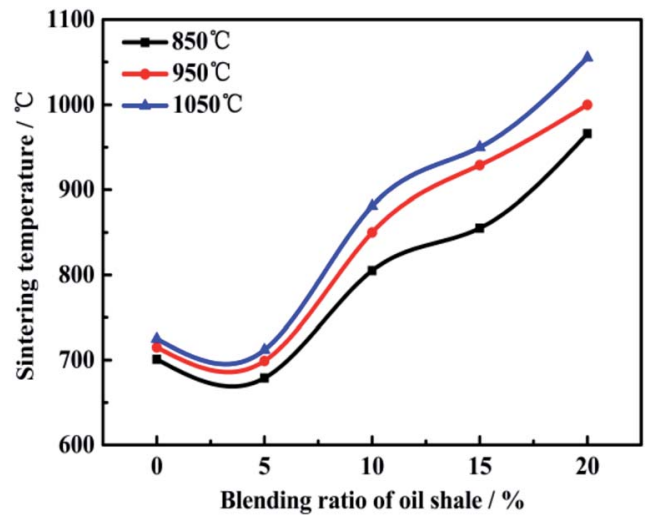

Fig. 4 Sintering temperature of ZD and mixed fuel ash heated at various temperatures. 
It can be obviously observed that the sintering temperatures of the ash depositions increase with an increase in temperature, which is attributed to the differences in mineral components of the ash depositions. According to the results of XRD above, more kinds and contents of refractory minerals with high melting point and high viscosity generate, which can result in high sintering temperature. As a result, the sintering temperature increases from $700{ }^{\circ} \mathrm{C}$ to $1055^{\circ} \mathrm{C}$, which can suppress ash sintering to a large extent.

\subsection{Sodium volatility of the ash}

Fig. 5 shows the variation trend of sodium volatilization rates at different blending ratios (0-20\%) and temperatures (850-1050 ${ }^{\circ} \mathrm{C}$ ). It has been founded that the oil shale blending ratio significantly influenced the sodium volatilization and such effect varied with the combustion temperature.

As shown in Fig. 5, during the combustion of "run of mine" Zhundong coal, 30-50\% sodium-based compounds volatilize to gaseous phase, and condense on the heat exchange surface and furnace wall, then react with $\mathrm{SO}_{2}, \mathrm{Fe}_{2} \mathrm{O}_{3}$ in the flue gas to generate various kinds of sulfates with low-melting-point and high-viscosity, ${ }^{44}$ such as sodium sulfate $\left(\mathrm{Na}_{2} \mathrm{SO}_{4}\right)$, compound sodium sulfate $\left(\mathrm{Na}_{3} \mathrm{Fe}\left(\mathrm{SO}_{4}\right)_{3}\right)$ and sodium pyrosulfate $\left(\mathrm{Na}_{2} \mathrm{~S}_{2} \mathrm{O}_{7}\right)$, which will form a compacted and cohesive sediment layer and result in high-temperature slagging, as shown in Fig. $6 .^{45}$ On the other hand, the fused boding layer would capture fly ash particles in the flue gas. These particles with lowsintering-temperature become fused and softened together through welding and bonding of the ambient particles, which led to high-temperature sintering. Therefore, it is widely assumed that the slagging caused by high-sodium coal results from the joint effects of high-temperature cohesive ash deposition and high-temperature sintering.

When blending Zhundong coal with a certain proportion of oil shale, the volatility of sodium-based compounds obviously reduces. It commendably shows that oil shale could inhibit sodium volatility with a significant effect during co-combustion. The sodium in Zhundong coal is captured by silicon and aluminum in oil shale, and then react to form the high-melting-

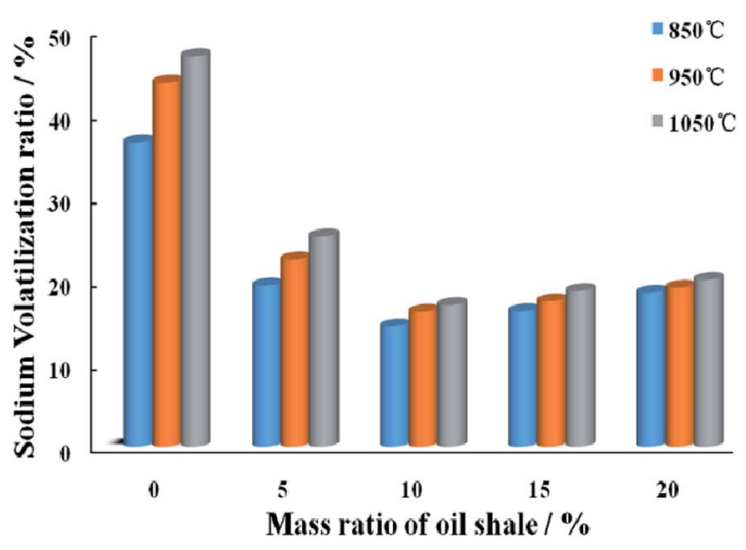

Fig. 5 Variation trend of sodium volatilization rates at different blending ratios and temperatures.

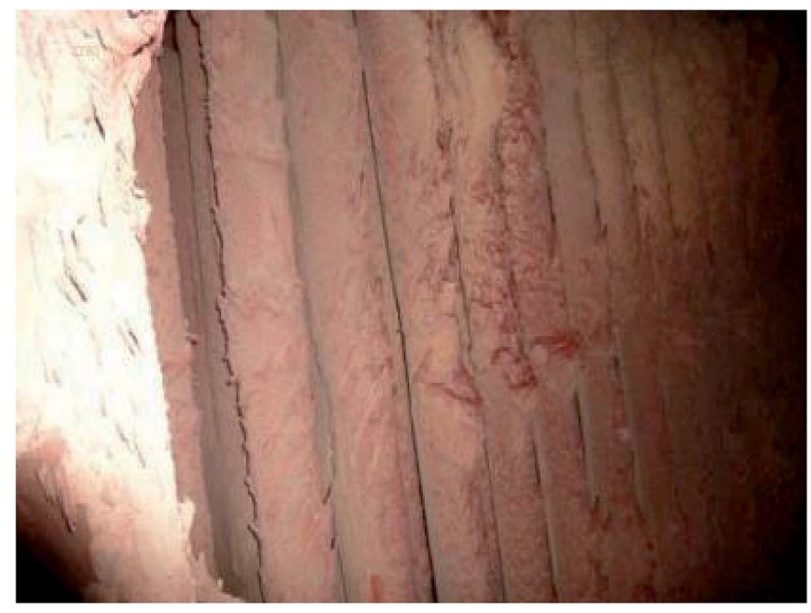

Fig. 6 Situation of slagging and deposition on the heat-transfer surface during Zhundong coal combustion.

point aluminosilicates, which can be exhausted to outside of the boiler by slag discharge system. In addition, with the proportion of oil shale increases, volatility rate of sodium-based compounds rapidly decreases first and then increases slowly under different temperatures. When the proportion reaches 5$10 \%$, oil shale reactivity is strong, and reacts rapidly with sodium in the ash, then volatility rate of sodium reduces obviously. When the proportion reaches $10 \%$, combustion temperature is $850{ }^{\circ} \mathrm{C}$, sodium volatility will decrease to its lowest point of $14.49 \%$. When the proportion further increases, the total content of sodium in the blending coal sample decreases, then the volatility rate will slightly increase.

At the same time, temperature has a profound effect on the release and transformation of sodium during Zhundong coal combustion. ${ }^{46}$ As the temperature increases from $850{ }^{\circ} \mathrm{C}$ to $1050{ }^{\circ} \mathrm{C}$, volatility of sodium in different blending coals all increase slightly, which partly results from the formation of mullite. This reaction will lead to provide less $\mathrm{SiO}_{2}$ and $\mathrm{Al}_{2} \mathrm{O}_{3}$ for sodium to form sodium aluminosilicates, which will reduce the chance of the capture sodium reaction. Furthermore, with an increase in temperature, the increase of release rate of sodium is always absolutely synchronous with that of oil shale's reaction of capturing sodium element. Since the release rate is higher than capturing rate, the volatility rate of sodium increased slightly. In addition, as the temperature increases, the separation of moisture and volatile in coal become faster, and watersoluble sodium arrives at the surface of coal ash particle with moisture through interspace, thus new channels from in the interior structure of coal, which further accelerates sodium volatility.

\section{Conclusions}

(1) The combustion temperature plays a significant role in the ash mineralogy transformation process, conversely, the oil shale ratio has little influence. The primary minerals in the Zhundong coal are mainly identified as anhydrite, quartz, thenardite and halite. After blending oil shale, some 
aluminosilicates formed, such as albite and nepheline, with an increase in temperature. The blending of oil shale can change the migration path of the sodium during combustion, indicating that sodium gradually migrated from the water-soluble phase to the aluminosilicate phase.

(2) The fluxing minerals, such as sodium-based and calciumbased compounds, with size less than $10 \mu \mathrm{m}$ are dominated in Zhundong coal. These fine particles may present in molten or sintering state at high temperature. After blending of oil shale, some refractory minerals with size exceeds $10 \mu \mathrm{m}$, such as nepheline, anorthite, form during co-combustion. These irregular particles retain their shapes during combustion resulting from their high melting temperatures. The amount of ash particle less than $10 \mu \mathrm{m}$ decreases from $84.31 \%$ to $40.29 \%$ with an increase in temperature.

(3) With an increase in the blending ratio of oil shale, the sintering temperature increases first and then decreases. When the blending ratio is in $\mathbf{0 - 5 \%}$, the sintering temperature decreases, because the proportion of mineral component is in the low-temperature eutectic region. When the blending ratio increase further, more kinds and contents of refractory minerals with high melting point and high viscosity generate, which can result in high sintering temperature. The sintering temperature increases from $700{ }^{\circ} \mathrm{C}$ to $1055{ }^{\circ} \mathrm{C}$, which can suppress ash sintering to a large extent.

(4) During combustion of Zhundong coal, 30-50\% sodiumbased compounds volatilize to gaseous phase. After blending Zhundong coal with some oil shale, with the proportion increases, volatility rate of sodium-based compounds decreases first and then increases. The effect of oil shale on inhibiting sodium volatility at low temperature is better than at high temperature. When the proportion reaches $10 \%$, combustion temperature is $850{ }^{\circ} \mathrm{C}$, sodium volatility will decrease to its lowest point of $14.49 \%$.

\section{Conflicts of interest}

There are no conflicts to declare.

\section{Acknowledgements}

This work was supported by the National Natural Science Foundation of China (Grant No. 21576182) and Shanxi Provincial Science and Technology Major Project (Grant No. MH201601).

\section{References}

1 J. Li, X. Zhuang, X. Querol, O. Font, N. Moreno and J. Zhou, Fuel, 2012, 95, 446-456.

2 J. Xu, D. Yu, B. Fan, X. Zeng, W. Lv and J. Chen, Energy Fuels, 2014, 28, 678-684.

3 J. H. Lv, X. Y. Wei, Y. H. Wang, T. M. Wang, J. Liu, D. D. Zhang and Z. M. Zong, RSC Adv., 2016, 6, 11952-11958.

4 J. Li, M. Zhu, Z. Zhang, Z. Kai, G. Shen and D. Zhang, Fuel Process. Technol., 2016, 144, 155-163.
5 J. Zhou, X. Zhuang, A. Alastuey, X. Querol and J. Li, Int. J. Coal Geol., 2010, 82, 51-67.

6 J. Li, M. Zhu, Z. Zhang and D. Zhang, Fuel, 2016, 179, 71-78.

7 X. Wang, Z. Xu, B. Wei, L. Zhang, H. Tan, T. Yang, H. Mikulčić and N. Duić, Appl. Therm. Eng., 2015, 80, 150159.

8 C. Du, L. Liu and P. Qiu, RSC Adv., 2017, 7, 10397-10406.

9 B. Gibson, S. Carter, A. Fisher, S. Lancaster, J. Marshall and I. Whiteside, J. Anal. At. Spectrom., 2015, 30, 1814-1869.

10 Y. Yang, Y. Wu, H. Zhang, M. Zhang, Q. Liu, H. Yang and J. Lu, Fuel, 2016, 181, 951-957.

11 J. Shen, H. Hu, M. Xu, H. Liu, K. Xu, X. Zhang, H. Yao and I. Naruse, Fuel, 2017, 207, 365-372.

12 B. Zhou, H. Zhou, J. Wang and K. Cen, Fuel, 2015, 150, 526537.

13 G. Li, S. Li, Q. Huang and Q. Yao, Fuel, 2015, 143, 430-437. 14 L. Chao, C. F. You and D. K. Zhang, Energy, 2014, 69, 562570.

15 M. J. F. Llorente, P. D. Arocas, L. G. Nebot and J. E. C. García, Fuel, 2008, 87, 2651-2658.

16 Z. Huang, L. Yan, L. Dan, Z. Zhou, Z. Wang, J. Zhou and K. Cen, Energy Fuels, 2013, 27, 2049-2056.

17 H. B. Vuthaluru and D. Zhang, Fuel Process. Technol., 1999, 60, 145-156.

18 S. Arvelakis, H. Gehrmann, M. Beckmann and E. G. Koukios, Biomass Bioenergy, 2002, 22, 55-69.

19 J. Barroso, J. Ballester, L. M. Ferrer and S. Jiménez, Fuel Process. Technol., 2006, 87, 737-752.

20 S. Su, J. H. Pohl and D. Holcombe, Fuel, 2003, 82, 1653-1667. 21 A. Rushdi, A. Sharma and R. Gupta, Fuel, 2004, 83, 495-506. 22 S. S. Lokare, J. D. Dunaway, D. Moulton, D. Rogers, D. R. Tree and L. L. Baxter, Energy Fuels, 2006, 20, 1008-1014.

23 B. H. Lee, S. I. Kim, S. M. Kim, D. H. Oh, S. Gupta and C. H. Jeon, Korean J. Chem. Eng., 2016, 33, 147-153.

24 M. Öhman, D. Boström, A. Nordin and H. Hedman, Energy Fuels, 2004, 18, 1370-1376.

25 F. Wigley, J. Williamson and G. Riley, Fuel Process. Technol., 2007, 88, 1010-1016.

26 T. Madhiyanon, P. Sathitruangsak, S. Sungworagarn, S. Fukuda and S. Tia, Fuel Process. Technol., 2013, 115, 182-191.

27 R. W. Bryers, Prog. Energy Combust. Sci., 1996, 22, 29-120.

28 H. Schürmann, S. Unterberger, K. R. Hein, P. B. Monkhouse and U. Gottwald, Faraday Discuss., 2001, 119, 433.

29 J. R. Wang, F. Chen, B. Zhao, X. Li and L. Qin, Fuel Process. Technol., 2016, 155, 209-215.

30 B. Wei, X. Wang, H. Tan, L. Zhang, Y. Wang and Z. Wang, Fuel, 2016, 181, 1224-1229.

31 L. Xu, L. Jie, K. Yong, Y. Miao, R. Wei and T. Wang, Energy Fuels, 2014, 28, 5640-5648.

32 Z. J. Liu and R. Liu, Earth Sci. Front., 2005, 12, 315-323.

33 N. Jing, Q. Wang, L. Cheng, Z. Luo, K. Cen and D. Zhang, Fuel, 2013, 104, 647-655.

34 I. Panagiotidis, K. Vafiadis, A. Tourlidakis and A. Tomboulides, Appl. Therm. Eng., 2015, 74, 156-164.

35 H. Zhou, B. Zhou, H. Zhang and L. Li, Energy Fuels, 2014, 28, 7701-7711. 
36 T. Sahraoui, H. Belhouchet, M. Heraiz, N. Brihi and A. Guermat, Ceram. Int., 2016, 42, 12185-12193.

37 A. Y. AlOtoom, G. W. Bryant, L. K. Elliott, B. J. Skrifvars, M. Hupa and T. F. Wall, Energy Fuels, 1999, 14, 41.

38 A. Y. Alotoom, L. K. Elliott, F. T. Wall and B. Moghtaderi, Energy Fuels, 2000, 14, 97-109.

39 F. Ishom, T. Harada, T. Aoyagi, K. Sakanishi, Y. Korai and I. Mochida, Fuel, 2002, 81, 1445-1451.

40 Y. Lu, Y. Wang, Y. Xu, Y. Li, W. Hao and Y. Zhang, Appl. Therm. Eng., 2017, 121, 224-233.

41 H. Naganuma, N. Ikeda, T. Ito, H. Satake, M. Matsuura, Y. Ueki, R. Yoshiie and I. Naruse, Fuel Abstr. Curr. Titles, 2013, 105, 77-81.
42 Q. H. Wang, N. J. Jing, Z. Y. Luo, L. I. Xiao-Min and T. Jie, J. China Coal Soc., 2010, 35, 1015-1020.

43 F. Li, J. R. Qiu and C. G. Zheng, J. Huazhong Univ. Sci. Technol., Med. Sci., 1996, 24, 577-584.

44 P. Radhakrishnan, V. Zakkay and A. Agnone, Combust. Sci. Technol., 1986, 50, 271-281.

45 S. Zhang, C. Chen, D. Shi, J. Li, J. Wang, X. Guo, A. Dong and S. Xiong, Proc. Chin. Soc. Electr. Eng., 2013, 33, 1-12.

46 G. Li, C. A. Wang, Y. Yan, X. Jin, Y. Liu and D. Che, J. Energy Inst., 2015, 29, 48-56. 